\section{Rapid validated HPTLC method for estimation of piperine and piperlongumine in root of Piper longum extract and its commercial formulation}

\author{
Anagha A. Rajopadhye, Tejas P. Namjoshi, Anuradha S. \\ Upadhye*
}

Plant Science Division, Agharkar Research Institute, India.

\begin{abstract}
Piperine and piperlongumine, alkaloids having diverse biological activities, commonly occur in roots of Piper longum L., Piperaceae, which have high commercial, economical and medicinal value. In present study, rapid, validated HPTLC method has been established for the determination of piperine and piperlongumine in methanolic root extract and its commercial formulation 'Mahasudarshan churna ${ }^{\circledR}$ ' using ICH guidelines. The use of Accelerated Solvent Extraction (ASE) as an alternative to conventional techniques has been explored. The methanol extracts of root, its formulation and both standard solutions were applied on silica gel $\mathrm{F}_{254}$ HPTLC plates. The plates were developed in Twin chamber using mobile phase toluene: ethyl acetate $(6: 4, v / v)$ and scanned at 342 and $325 \mathrm{~nm}$ ( $\lambda_{\max }$ of piperine and piperlongumine, respectively) using Camag TLC scanner 3 with CATS 4 software. A linear relationship was obtained between response (peak area) and amount of piperine and piperlongumine in the range of 20-100 and 30-150 ng/spot, respectively; the correlation coefficient was 0.9957 and 0.9941 respectively. Sharp, symmetrical and well resolved peaks of piperine and piperlongumine spots resolved at $\mathrm{R}_{\mathrm{f}} 0.51$ and 0.74 , respectively from other components of the sample extracts. The HPTLC method showed good linearity, recovery and high precision of both markers. Extraction of plant using ASE and rapid HPTLC method provides a new and powerful approach to estimate piperine and piperlongumine as phytomarkers in the extract as well as its commercial formulations for routine quality control.
\end{abstract}

Revista Brasileira de Farmacognosia Brazilian Journal of Pharmacognosy 22(6): 1355-1361, Nov./Dec. 2012

Article

Received 4 May 2012

Accepted 22 Aug 2012

Available online 20 Sep 2012

\section{Keywords:}

Accelerated Solvent Extraction HPTLC piperine

piperlongumine polyherbal formulation root of Piper longum

ISSN 0102-695X http://dx.doi.org/10.1590/S0102695X2012005000113

\section{Introduction}

Root of Piper longum L., Piperaceae, is used in home remedies as well as Indian System of Traditional Medicine against various disorders like pasly, gout, rheumatism, lumbago, bronchitis and abortifacient (Kirtikar \& Basu, 1984). It is a major constituent of many common Ayurvedic and polyherbal formulations such as 'Mahasudarshan churna' which is used for complications associated with fever, typhoid, jwar etc. (Desai, 1975; Kirtikar \& Basu, 1984; Deshpande et al., 1989). Root is reported as antiamoebic (Ghoshal \& Lakshmi, 2002), analgesic (Vedhanayaki et al., 2003), hepatoprotective (Patel \& Shah, 2009), antioxidant (Jagdale et al., 2009) and antimicrobial (Gupta et al., 2010) activity. It is a well known source of pharmacologically active alkaloids piperine (1) [CAS 94-62-2] and piperlongumine (2) [CAS 20069-09-4] (Dutta et al., 1977).

Piperine (1) is reported for diverse therapeutic actions like central nervous system depressant, analgesic (Singh et al., 1973), inhibition of hepatic drug metabolism (Bhat \& Chandrasekhara, 1987), enhancing pentobarbitone induced hyponosis (Mujumdar et al., 1990a), bioavailability of oxyphenylbutazone (Mujumdar et al., 1999), hepatoprotective activity (Desai et al., 2008), anti-inflammatory activity (Mujumdar et al., 1990b), inhibition of lipid peroxidation during experimental inflammation (Dhuley et al., 1993), devoid of genotoxic effects (Karekar et al., 1996), antifertility (Daware et al., 2000) and antidiarrhoeal (Bajad et al., 2001). It also possesses radioprotective effects (Aggarwal \& Kaul, 1992). Piperlongumine (2) is reported for killing of cancer cells by a small molecule targeting the stress response to ROS (Raj et al., 2011), antiplatelet (Lee et al., 2010), melanocyte stimulatory activity (Lin et al., 2007). It also acts as an antiaflatoxin agent (Lee et al., 2002). Due to diverse therapeutic activities, both compounds can be used as marker compounds for quality control and standardization of 
root of $P$. longum. A perusal of literature showed no reports are available on analytical methods for analysis of piperine and piperlongumine in roots of this plant, its extracts or commercial formulations. Hence, the aim of this study was development and validation of a new, low-cost and high throughout analytical method for simultaneous quantitation of piperine and piperlongumine in methanolic root extract of $P$. longum as well as its commercial product 'Mahasudarshan churna' using ICH guidelines (ICH, 1996) and also assesses the possible application of Accelerated Solvent Extraction (ASE) in extracting both bioactive markers.

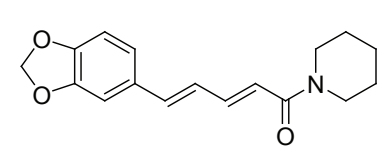

1

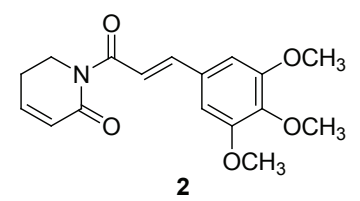

2 yield was obtained in methanol with extraction time of $480 \mathrm{~min}(8 \mathrm{~h})$. The extract was then filtered through Whatman no. 41 (E. Merck, Mumbai, India) and concentrated under reduced temperature and pressure using rotary evaporator. The extractions were performed in triplicate. Respective yields of methanol extract of root and formulation sample were $1.602 \pm 3.56$ and $0.901 \pm 3.78 \mathrm{~g}$.

\section{Accelerated solvent extraction}

Accurately weighed powder of root sample (5 g) and 'Mahasudarshan churna ${ }^{\mathbb{B}}$ ' sample were extracted with methanol placed in the stainless-steel cell of a Dionex ASE ${ }^{\mathrm{TM}} 100$ system (Sunnyvale, CA, USA). Extraction was performed at 100 bar and three temperatures, 40,60 and $80^{\circ} \mathrm{C}$, for $20 \mathrm{~min}(1 \mathrm{cycle})$. The optimum yield was obtained at $60^{\circ} \mathrm{C}$. In the experiment at $60{ }^{\circ} \mathrm{C}$, five replicate cycles were performed. The extracts were concentrated under reduced temperature and pressure using rotary evaporator. The extractions were performed in triplicate. Respective yields of methanol extract of root and formulation sample were $1.718 \pm 2.89$ and $1.052 \pm 4.78 \mathrm{~g}$.

Root of Piper longum L., Piperaceae, was collected from Amboli, Maharashtra, India in January 2009. The sample was authenticated by Dr. A. S. Upadhhye and deposited in the Agharkar Herbarium at Maharashtra Association of Cultivation Sciences, Agharkar Research Institute, Pune, vide voucher specimen number AHMA-0025384.

'Mahasudarshan churna ${ }^{\circledR}$ ' (Shree Baidyanath Ayurved Bhawan Pvt. Ltd., Napur, India) was procured from local market, Pune, India. Silica gel $F_{254}$ HPTLC plates were purchased from Merck, Darmstadt, Germany. Other analytical grade solvents and reagents were obtained from sd fine chemicals, Mumbai, India.

\section{Isolation of piperine and piperlongumine}

Piperine (1) and piperlongumine (2) were isolated from roots of $P$. longum using the method reported by Chatterjee \& Dutta (1967). The isolated compounds showed single spot on TLC. The crystallized pure compounds $(\geq 97 \%)$ were identified based on melting point, UV and co-TLC with reference piperine and piperlongumine (Sigma Aldrich, Germany).

\section{Sample extraction procedure for HPTLC analysis}

\section{Soxhlet extraction}

Accurately weighed powder of root sample (5 g) and 'Mahasudarshan churna ${ }^{\circledR}$ ' sample were extracted exhaustively with methanol $(100 \mathrm{~mL})$ using Soxhlet apparatus for $360-600 \mathrm{~min}(6-10 \mathrm{~h})$. The optimum

\section{Chromatographic experiments}

HPTLC analysis was performed on aluminium backed HPTLC plates $10 \times 10 \mathrm{~cm}$ coated with $0.2 \mathrm{~mm}$ layers of silica gel $60 \mathrm{~F}_{254}$ (E. Merck, Germany). Samples $(4 \mu \mathrm{L})$ were applied on the plate with band width $6 \mathrm{~mm}$ employing Linomat IV sample applicator (Camag, Switzerland) fitted with a microlitre syringe. Linear ascending development of the plate to a distance of 80 $\mathrm{mm}$ was performed with mobile phase toluene:ethyl acetate $(6: 4, v / v)$ in a twin-trough glass chamber previously saturated with mobile phase vapour for 10 min at $25^{\circ} \mathrm{C}$. The dried plate was scanned at wavelength of 342 and $325 \mathrm{~nm}$ ( $\lambda_{\text {max }}$ of piperine and piperlongumine, respectively) using a Camag TLC scanner 3 with CATS 4 software. A variety of mobile phases were tried for analysis of piperine and piperlongumine in methanolic extracts of root and commercial formulation. These included toluene :ethyl acetate :diethyl ether $(6: 3: 1$, $v / v / v)$, toluene:ethyl acetate:diethyl ether $(5: 4: 1, v / v / v)$, toluene:ethyl acetate $(7: 3 \mathrm{v} / \mathrm{v})$, toluene:ethyl acetate $(5: 5, v / v)$.

Calibration plot of piperine and
piperlongumine

Stock solutions of piperine and piperlongumine were individually prepared by dissolving pure substances at concentrations of $1.0 \mathrm{mg} / \mathrm{mL}$ in methanol. Standard solutions were prepared by diluting the stock 
solutions with methanol to obtain concentrations of $1,2,3,4$ and $5 \mu \mathrm{g} / \mathrm{mL}$ for different concentrations of piperine $(20,40,60,80$ and $100 \mathrm{ng}$, respectively) and $1.5,3,4.5,6$ and $7.5 \mu \mathrm{g} / \mathrm{mL}$ for different concentrations of piperlongumine $(30,60,90,120$ and $150 \mathrm{ng}$, respectively).

Quantification of piperine and
piperlongumine

Each test extract $(2.5 \mathrm{mg})$ was dissolved in methanol $(2 \mathrm{~mL})$ to serve as test solution for HPTLC analysis. Test sample solutions $4 \mu \mathrm{L}(5000$ ng) were applied in duplicate on a HPTLC plate along with standards. The plate was developed under predetermined conditions described above and scanned at 342 and $325 \mathrm{~nm}$ ( $\lambda_{\max }$ of piperine and piperlongumine, respectively). Peak areas were recorded and piperine and piperlongumine content in the samples were calculated using the calibration plot.

\section{Validation}

The method was validated according to the ICH guidelines (ICH, 1996) by determining peak purity, limit of detection (LOD), limit of quantitation (LOQ), precision and recovery of piperine and piperlongumine from test samples.

Instrument precision was checked by repeated scanning of piperine and piperlongumine band ( 80 and $120 \mathrm{ng}$, respectively) six times and expressed as relative standard deviation $(\% R S D)$. Precision was studied by analyzing six bands of sample solutions per plate on three plates (intra-day precision) and by analyzing six bands of sample solution per plate on three consecutive days (inter-days precision) at three different quantities (40, 60, $80 \mathrm{ng} / \mathrm{spot}$ for piperine; 60, 90, $120 \mathrm{ng} / \mathrm{spot}$ for piperlongumine) and calculated $\% R S D$. Accuracy of the method was tested by determination of recovery at three levels. Pre-analyzed samples were spiked with extra individual standards (50,100 and $150 \%)$ and the mixtures were reanalyzed. Robustness of the method was studied at three different concentrations - 40, 60, $80 \mathrm{ng} / \mathrm{spot}$ for piperine; $60,90,120 \mathrm{ng} / \mathrm{spot}$ for piperlongumine by introducing small deliberate changes in mobile phase composition (toluene:ethyl acetate, 6.2:3.8, 5.8:4.2, v/v). Repeatability of the method was assessed by analysis of 60 and $90 \mathrm{ng} / \mathrm{spot}$ of standard solutions of piperine and piperlongumine $(\mathrm{n}=6)$, respectively and expressed as $R S D(\%)$ of peak areas. Percentage recovery and standard deviation (SD) were calculated for each concentration level. LOD and LOQ were determined by standard deviation (SD) method from the slope $(S)$ of calibration plot and the SD of a blank sample (blank methanol was spotted three times), by use of the equations $\mathrm{LOD}=3.3 \times \mathrm{SD} / \mathrm{S}$ and $\mathrm{LOQ}=10 \times \mathrm{SD} / S$.

\section{Results and Discussion}

Accelerated solvent extraction (ASE) was studied along with Soxhlet extraction for the development of rapid sample preparation method. ASE was being applied for the first time for extraction of piperine and piperlongumine in Piper longum L., Piperaceae, root extract. The mobile phase toluene:ethyl acetate $(6: 4, v / v)$ gave optimized result with sharp, symmetrical and well resolved peaks of piperine and piperlongumine at $R_{f} 0.51$ and 0.74 , respectively from other components of the sample extracts (Figure 1). A linear relationship was obtained between response (peak area) and amount of piperine and piperlongumine in the range of 20-100 and 30-150 ng/spot, respectively; the correlation coefficient was 0.9957 and 0.9941, respectively. Piperine (1) and piperlongumine (2) in the methanolic extract of $P$. longum roots were quantitated using the developed HPTLC method and the results for each extraction technique employed are summarized in Table 1. Both the marker compounds were observed in chromatograms of all sample extracts with variation in their contents. As evident, ASE at $60^{\circ} \mathrm{C}$ for 20 min gave almost the same results as in Soxhlet extraction for 480 min (Table 1). However, taking into consideration the time of extraction and solvent consumption, ASE proves to be a promising alternative to Soxhlet extraction.

The method was validated in terms of peak purity, precision, LOD, LOQ and accuracy (Tables 2-4). Method was specific for analysis of both active principles piperine and piperlongumine because it resolved the compounds at $R_{f} 0.51$ and 0.74 , respectively in the presence of other components. Purity of piperine and piperlongumine peak was checked from the samples by recording UV spectra. The method selectivity was demonstrated by the absence of overlapping spots. The identified spots of piperine and piperlongumine were confirmed from sample extracts by overlaying UV absorption spectrum of samples with standards at 342 and $325 \mathrm{~nm}$, respectively.

The $\%$ RSD of instrument precision for peak area of piperine and piperlongumine was found to be 0.61 and 0.72 , respectively. Intra-day and inter-days precision were studied by triplicate assay at three different quantities $(40,60,80 \mathrm{ng} / \mathrm{spot}$ for piperine; 60, 90, $120 \mathrm{ng} / \mathrm{spot}$ for piperlongumine). Low RSD values (Table 2) indicated the method was precise. Small changes in mobile phase composition had no significant effect on the chromatographic profile. Low RSD values of peak areas calculated indicate robustness of the method (Table 4). Accuracy of the method was determined at three levels $(50,100$, and $150 \%)$ by 
adding known amounts of standards to samples extract. The result is represented in Table 3 . High recovery indicated that the proposed method was reliable and reproducible. LOD was found to be 6.66 and $10 \mathrm{ng} /$ spot for piperine and piperlongumine, respectively. LOQ was found to be 20 and $30 \mathrm{ng} / \mathrm{spot}$ for piperine and piperlongumine, respectively.

Herbal drug, singularly or in combinations is a multifarious mixture of phytoconstitutes in which no single constituent is responsible for the overall efficacy. It leads to create a challenge in establishing quality control standards for raw materials and the standardization of finished herbal drugs. Selecting one or more markers is a common practice in natural product analysis for purposes of identification and quality assessment. Estimation of the content of marker in herbal medicine is important in evaluating the phytochemical entity of the herb. Roots of $P$. longum are commonly used in various polyherbal formulations. In present study, a new, simple, accurate, precise, reproducible and sensitive HPTLC method was developed for simultaneous determination of piperine and piperlongumine in root of $P$. longum and its commercial product 'Mahasudarshan churna ${ }^{\circledR}$ '. Comparison of the extraction yields of both markers reveals ASE is a simple and efficient method. The method will be helpful for standardization and routine quality control of raw materials and herbal products containing root of $P$. longum as an ingredient. It provides significant advantages in terms of greater specificity and rapid analysis.

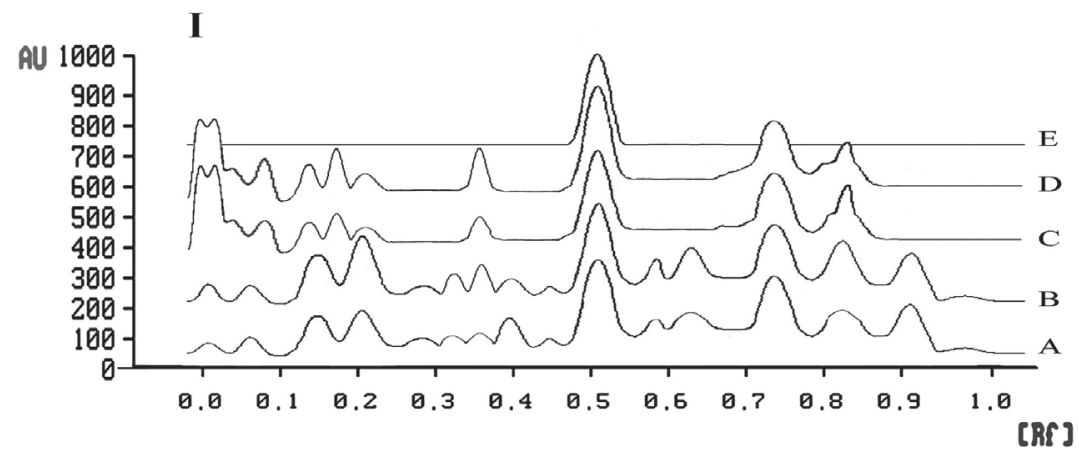

II

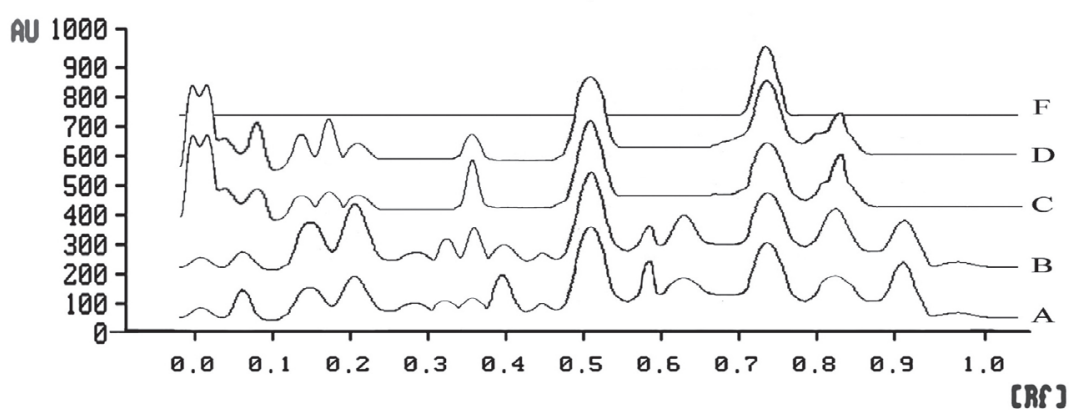

Figure 1. HPTLC chromatograms of methanolic extracts of root of Piper longum, its formulation along with standards piperine and piperlongumine. (I) For piperine standard scanned $\lambda 342 \mathrm{~nm}$; (II) for piperlongumine scanned at $\lambda 325 \mathrm{~nm}$. A. methanolic Soxhlet extract of root; B. methanolic ASE $60^{\circ} \mathrm{C}$ extract of root; C. methanolic Soxhlet extract of formulation; D. methanolic ASE $60^{\circ} \mathrm{C}$ extract of formulation; E. standard piperine; F. standard piperlongumine.

Table 1. Comparative content of piperine and piperlongumine in extracts of $P$. longum root and its formulation.

\begin{tabular}{lcc}
\hline \multicolumn{1}{c}{ Sample } & Piperine $\mathrm{mg} / \mathrm{g}$ & Piperlongumine $\mathrm{mg} / \mathrm{g}$ \\
\hline Soxhlet extraction - methanol extract of root & $9.56 \pm 0.83$ & $4.67 \pm 1.23$ \\
ASE $60^{\circ} \mathrm{C}$ extraction - methanol extract of root & $9.91 \pm 0.98$ & $5.09 \pm 0.97$ \\
Soxhlet extraction - methanol extract of formulation & $0.23 \pm 0.05$ & $0.11 \pm 0.03$ \\
ASE $60^{\circ} \mathrm{C}$ extraction - methanol extract of formulation & $0.27 \pm 0.09$ & $0.17 \pm 0.04$ \\
\hline
\end{tabular}

Values are mean $\pm \mathrm{SD}$ of three experiments. 
Table 2. Validation data of HPTLC method for estimation of piperine and piperlongumine.

\begin{tabular}{|c|c|c|}
\hline Parameters & piperine & piperlongumine \\
\hline Instrumental precision $(\% \mathrm{RSD}, \mathrm{n}=6)$ & 0.61 & 0.72 \\
\hline Calibration range (ng/spot) & $20-100$ & $30-150$ \\
\hline Regression equation & $y=309.78 x+801.85$ & $y=3.0345 x+1380.9$ \\
\hline Correlation coefficient & 0.9957 & 0.9941 \\
\hline Repeatability of standards ( $\%$ RSD , $n=6)$ & 0.57 & 0.56 \\
\hline Repeatability of samples ( $\%$ RSD, $n=6$ ) & 0.91 & 0.94 \\
\hline Limit of detection (LOD) (ng/spot) & 6.66 & 10 \\
\hline Limit of quantitation (LOQ) (ng/spot) & 20 & 30 \\
\hline Intra-day precision $(\% \mathrm{RSD}, \mathrm{n}=6)$ & 0.97 & 0.98 \\
\hline Inter-day precision ( $\% \mathrm{RSD}, \mathrm{n}=6)$ & 0.78 & 1.12 \\
\hline
\end{tabular}

Table 3. Recovery study of the method for standards piperine and piperlongumine.

\begin{tabular}{|c|c|c|c|c|c|}
\hline Compound & $\begin{array}{l}\text { Amount of standard in } \\
\text { sample [ng] }{ }^{\mathrm{a}}\end{array}$ & $\begin{array}{l}\text { Amount of standard } \\
\text { added [ng] }\end{array}$ & $\begin{array}{l}\text { Amount of standard } \\
\text { found in mixture }[\mathrm{ng}]^{\mathrm{a}}\end{array}$ & Recovery $[\%]^{\mathrm{a}}$ & $\begin{array}{c}\text { Average recovery } \\
{[\%]^{a}}\end{array}$ \\
\hline \multicolumn{6}{|c|}{ Soxhlet extraction - methanol extract of root } \\
\hline \multirow[t]{3}{*}{ piperine } & $316 \pm 8.33$ & 158 & $456 \pm 4.33$ & $96.20 \pm 2.22$ & $94.97 \pm 3.43$ \\
\hline & $316 \pm 8.33$ & 316 & $600 \pm 5.87$ & $94.93 \pm 3.45$ & \\
\hline & $316 \pm 8.33$ & 474 & $741 \pm 9.03$ & $93.79 \pm 3.85$ & \\
\hline \multicolumn{6}{|c|}{ ASE $60^{\circ} \mathrm{C}$ - methanol extract of root } \\
\hline \multirow[t]{3}{*}{ piperine } & $316 \pm 8.33$ & 158 & $451 \pm 3.84$ & $95.55 \pm 4.25$ & $95.94 \pm 3.67$ \\
\hline & $316 \pm 8.33$ & 316 & $608 \pm 4.23$ & $96.20 \pm 2.45$ & \\
\hline & $316 \pm 8.33$ & 474 & $759 \pm 3.08$ & $96.07 \pm 1.56$ & \\
\hline \multicolumn{6}{|c|}{ Soxhlet extraction - methanol extract of root } \\
\hline \multirow[t]{3}{*}{ piperlongumine } & $234 \pm 5.67$ & 117 & $329 \pm 1.56$ & $93.23 \pm 2.35$ & $94.38 \pm 1.89$ \\
\hline & $234 \pm 5.67$ & 234 & $438 \pm 2.95$ & $93.58 \pm 3.54$ & \\
\hline & $234 \pm 5.67$ & 351 & $567 \pm 3.98$ & $96.92 \pm 1.89$ & \\
\hline \multicolumn{6}{|c|}{ ASE $60^{\circ} \mathrm{C}$ - methanol extract of root } \\
\hline \multirow[t]{3}{*}{ piperlongumine } & $234 \pm 5.67$ & 117 & $321 \pm 2.34$ & $91.45 \pm 3.34$ & $93.72 \pm 2.78$ \\
\hline & $234 \pm 5.67$ & 234 & $441 \pm 4.14$ & $94.23 \pm 2.53$ & \\
\hline & $234 \pm 5.67$ & 351 & $559 \pm 3.67$ & $95.48 \pm 5.89$ & \\
\hline \multicolumn{6}{|c|}{ Soxhlet extraction - methanol extract of formulation } \\
\hline \multirow[t]{3}{*}{ piperine } & $105 \pm 3.78$ & 52.5 & $146 \pm 1.98$ & $92.71 \pm 2.09$ & $95.09 \pm 2.56$ \\
\hline & $105 \pm 3.78$ & 105 & $199 \pm 2.07$ & $95.22 \pm 3.55$ & \\
\hline & $105 \pm 3.78$ & 157.5 & $255 \pm 2.35$ & $97.36 \pm 1.01$ & \\
\hline \multicolumn{6}{|c|}{ ASE $60^{\circ} \mathrm{C}$ extraction - methanol extract of formulation } \\
\hline \multirow[t]{3}{*}{ piperine } & $105 \pm 3.78$ & 52.5 & $149 \pm 3.16$ & $94.63 \pm 2.90$ & $94.80 \pm 1.03$ \\
\hline & $105 \pm 3.78$ & 105 & $199 \pm 2.67$ & $94.77 \pm 3.63$ & \\
\hline & $105 \pm 3.78$ & 157.5 & $250 \pm 2.39$ & $95.01 \pm 4.91$ & \\
\hline \multicolumn{6}{|c|}{ Soxhlet extraction - methanol extract of formulation } \\
\hline \multirow[t]{3}{*}{ piperlongumine } & $78 \pm 6.89$ & 39 & $115 \pm 2.21$ & $98.61 \pm 1.67$ & $96.67 \pm 2.34$ \\
\hline & $78 \pm 6.89$ & 78 & $151 \pm 3.67$ & $97.32 \pm 1.66$ & \\
\hline & $78 \pm 6.89$ & 117 & $185 \pm 3.09$ & $95.01 \pm 3.04$ & \\
\hline \multicolumn{6}{|c|}{ ASE $60^{\circ} \mathrm{C}$ - methanol extract of formulation } \\
\hline \multirow[t]{3}{*}{ piperlongumine } & $78 \pm 6.89$ & 39 & $109 \pm 1.44$ & $93.85 \pm 2.34$ & $95.24 \pm 2.98$ \\
\hline & $78 \pm 6.89$ & 78 & $147 \pm 2.39$ & $94.55 \pm 3.48$ & \\
\hline & $78 \pm 6.89$ & 117 & $189 \pm 2.11$ & $97.33 \pm 1.02$ & \\
\hline
\end{tabular}

${ }^{\mathrm{a}} \operatorname{Mean} \pm \operatorname{SD}(\mathrm{n}=3)$. 
Table 4. Robustness of the method for standards piperine and piperlongumine.

\begin{tabular}{|c|c|c|c|}
\hline Condition & $\begin{array}{l}\text { Amount of standard added } \\
(\text { (ng/spot })^{\mathrm{a}}\end{array}$ & $\begin{array}{l}\text { Amount of standard detected } \\
\qquad(\mathrm{ng} / \mathrm{spot})^{\mathrm{a}}\end{array}$ & $\%$ RSD \\
\hline \multicolumn{4}{|c|}{ Mobile phase composition - toluene:ethyl acetate, $6.2: 3.8, v / v$} \\
\hline \multirow[t]{3}{*}{ piperine } & 40 & $39.78 \pm 1.34$ & 1.09 \\
\hline & 60 & $60.01 \pm 1.56$ & 0.87 \\
\hline & 80 & $79.01 \pm 1.7$ & 0.76 \\
\hline \multirow[t]{3}{*}{ piperlongumine } & 60 & $59.33 \pm 1.34$ & 0.78 \\
\hline & 90 & $88.45 \pm 1.23$ & 1.1 \\
\hline & 120 & $118.99 \pm 1.97$ & 0.98 \\
\hline \multicolumn{4}{|c|}{ Mobile phase composition - toluene:ethyl acetate, $5.8: 4.2, v / v$} \\
\hline \multirow[t]{3}{*}{ piperine } & 40 & $38.88 \pm 1.45$ & 1.45 \\
\hline & 60 & $59.05 \pm 2.01$ & 0.81 \\
\hline & 80 & $79.44 \pm 1.34$ & 0.89 \\
\hline \multirow[t]{3}{*}{ piperlongumine } & 60 & $58.91 \pm 1.56$ & 0.99 \\
\hline & 90 & $88.97 \pm 1.73$ & 1.45 \\
\hline & 120 & $118.01 \pm 1.72$ & 1.01 \\
\hline
\end{tabular}

${ }^{\mathrm{a}} \operatorname{Mean} \pm \operatorname{SD}(\mathrm{n}=3)$.

\section{Acknowledgments}

The authors are greatly thankful to the Director and the In-charge, Botany group, Agharkar Research Institute, Pune, India for providing facilities and encouragement throughout the work.

\section{References}

Aggarwal M, Kaul BL 1992. The radioprotective effect of piperine in plants. Indian Drugs 29: 447-449.

Bajad S, Bedi KL, Singla AK, Johri RK 2001. Piperine inhibits gastric emptying and gastrointestinal transit in rats and mice. Planta Med 67: 284-287.

Bhat BG, Chandrasekhara N 1987. Effect of black pepper and piperine on bile secretion and composition in rats. Nahrung 3: 913-916.

Chatterjee A, Dutta CP 1967. Alkaloids of Piper longum. I. Structure and synthesis of piperlongumine and piperlonguminine. Tetrahedron 23: 1769-1781.

Daware MB, Mujumdar AM, Ghaskadbi S 2000. Reproductive toxicity of piperine in Swiss albino mice. Planta Med 66: 231-236.

Desai SK, Gawali VS, Naik AS, D'souza LL 2008. Potentiating effect of piperine on hepatoprotective activity of Boerhaavia diffusa to combat oxidative stress. Int $J$ Pharmacogn 4: 393-397.

Desai VG 1975. Aushadhi Sangraha. Bombay, India: Shri Gajanan Book Depot.

Deshpande AP, Javalgekar RR, Rande S 1989. Dravyagunvidhyan. Pune, India: Anmola Prakhashan.

Dhuley JN, Raman PH, Mujumdar AM, Naik SR 1993.
Inhibition of lipid peroxidation by piperine during experimental inflammation in rats. Indian J Exp Biol 31: 443-445.

Dutta CP, Banerjee N, Sil AK, Roy DN 1977. Studies on the genus Piper: studies on the roots of Piper longum Linn. Indian J Chem B 15: 583-584.

Ghoshal S, Lakshmi V 2002. Potential antiamoebic property of the roots of Piper longum Linn. Phytother Res 16: 689-691.

Gupta PC, Garg N, Pant D, Joshi P, Lohar DR 2010. Antimicrobial activity and HPTLC profiling of Piper longum Linn. after microbial decontamination by gamma irradiation. J Pure Appl Microbiol 4: 69-77.

ICH 1996. Validation of Analytical Procedures: MethodologyICH Harmonised Tripartite Guideline (Q2B). International Conference on Harmonization.

Jagdale SC, Kuchekar BS, Chabukswar AR, Lokhande PD, Raut CG 2009. Antioxidant activity of Piper longum Linn. Int J Biochem 3: 119-125.

Karekar VR, Mujumdar AM, Joshi SS, Dhuley JN, Shinde SL, Ghaskadbi SM 1996. Assessment of genotoxic effect of piperine using Salmonella typhimurium and somatic and somatic and germ cells of Swiss albino mice. Arzneim-Forsch/Drug Resist Update 46: 972975.

Kirtikar KR, Basu BD 1984. Piper longum Linn., Indian Medicinal Plants, Vol. 3. New Delhi, India: Periodical Expert Book Agency.

Lee S-E, Mahoney NE, Campbell BC 2002. Inhibition of aflatoxin B1 biosynthesis by piperlongumine isolated from Piper longum L. J Microbiol Biotechn 12: 679682. 
Lee S-E, Park B-S, Huh T-L, Lee E-W, Yum JH 2010. Proteomic evaluation on antiplatelet activity of piperlongumine derived from Piper longum. Mol Cell Toxicol 6: 295-303.

Lin Z, Liao Y, Venkatasamy R, Hider RC, Soumyanath A 2007. Amides from Piper nigrum L. with dissimilar effects on melanocyte proliferation in-vitro. J Pharm Pharmacol 59: 529-536.

Mujumdar AM, Dhuley JN, Deshmukh VK, Naik SR 1999. Effect of piperine bioavailability of oxyphenylbutazone in rats. Indian Drugs 36: 123-126.

Mujumdar AM, Dhuley JN, Deshmukh VK, Raman PH, Thorat SL, Naik SR 1990a. Effect of piperine on pentobarbitore induced hypnosis in rats. Indian J Exp Biol 28: 486-487.

Mujumdar AM, Dhuley JN, Deshmukh VK, Raman PH, Naik SR 1990b. Antiinflammatory activity of piperine. Jpn J Med Sci Biol 43: 95-100.

Patel JA, Shah US 2009. Hepatoprotective activity of Piper longum traditional milk extract on carbon tetrachloride induced liver toxicity in Wistar rats. Caribe Plant Med Aromat 8: 121-129.
Raj L, Ide T, Gurkar AU, Foley M, Schenone M, Li X, Tolliday NJ, Golub TR, Carr SA, Shamji AF, Stern AM, Mandinova A, Schreiber SL, Lee SW 2011. Selective killing of cancer cells by a small molecule targeting the stress response to ROS. Nature 475: 231-234.

Singh N, Kulshrestha VK, Srivastava RK, Kohli RP 1973. A comparative evaluation of piperine and nalorphine against morphine induced respiratory depression and analgesia. J Res Indian Med 8: 21-26.

Vedhanayaki G, Shastri GV, Kuruvilla A 2003. Analgesic activity of Piper longum Linn. root. Indian J Exp Biol 41: 649-651.

\section{*Correspondence}

Anuradha S. Upadhye

Agharkar Research Institute, G. G. Agarkar Road, Pune, India

anuradhaupadhye@aripune.org

Tel.: +0202565 4357

Fax: +020 25651542 